\title{
STUDIES ON CHEMICAL COMPOSITION OF CUTTLEFISH (SEPIA SP.) MEAT AS RELATED TO ITS NUTRITIVE VALUE
}

\section{BADANIA NAD SKEADEM CHEMICZNYM I WARTOŚCIAZ ODŻYWCZA MIEZSA MAZTWY (SEPIA SP)}

From Department of Fish Processing Technology

The chemical composition of edible cuttlefishflesh, distinguishing it into the mantle and arms together with part of head was examined. Comparison between the chemical composition of cuttlefish flesh and that of squid, originating from the same fishing ground and catching period was carried out also.

\section{INTRODUCTION}

The rising demand for animal protein throughout the world on the one hand and, on the other the slow but visible reduction of fish stocks forces us to reach out for the non-fish resources of the sea at present exploited to a limited extent only, which include, among others, the cephalopods.

In the last few years world catches of squid and cuttlefish have oscilatted between 1 and 1.8 per cent of the total catches of salt-water fish (FAO, UN, 1957 ); it is a known fact, however, that the amounts could easily be multiplied, particularly from the resources of the north and middle-Atlantic, as well as the North Sea, at present only partially exploited (K l a r k, 1964). Former investigations on the utilization of cephalopods in nutrition, carried out mainly on squid ( $\mathrm{T}$ a k a h a s h i, 1965; Lagu n ov and R e h i na, 1967), showed that they are valuable material for processing. Cuttlefish is treated off-handedly in these studies andis as a raw material for processing often identified with squid under the common heading of "cephalopods".

In literature, only one or two papers make fragmentary mention of the chemical composition and nutritive value of cuttlefish flesh (I t o, 1957; M ac i e j s z y k, 1968).

This work the aim of which, among others, was to supplement the scanty data, gives the basic chemical composition of cuttlefish flesh, the composi- 
tion of free and bound amino acids in the protein, caloric value of the flesh and also the properties of proteins from the point of view of their solubility. Attention was paid to the fundamental differencies in the chemical composition of cuttlefish and already previously examined squid flesh, originating from the same fishing ground and catching period.

\section{MATERIALS AND METHODS}

Cuttlefish (Sepia sp.) were caught in July, 1967 on the mid.-east Atlantic fishing grounds on the Mauretanian coast in the square from $17^{\circ} 52^{\prime}$ to $21^{\circ} 33^{\prime} \mathrm{N}$ and from $16^{\circ} 19^{\prime}$ to $17^{\circ} 39^{\circ} \mathrm{W}$. Immediately after catching the cuttlefish was frozen in an "Atlas"-type contact freezer at a temperature of $-20^{\circ} \mathrm{C}$ and carried frozen to the laboratory in Poland. The total time from the extraction to the sampling of the cuttlefish for chemical analysis purposes, was 43 days.

\section{Morphometric analysis}

After partial defreezing of the cuttlefishblocks at room temperature in the open air, undamaged pieces were chosen and underwent morphometric analysis; measured were: length (distance from the socket joints of arms to the end of the mantle); total weight of the cuttlefish; weight of the mantle (excluding the internal skeleton); weight of the arms and part of the head (excluding keratose beak) and weight of inedible parts), intestines, skeleton, keratose beak, inksac).

\section{Preparation of samples for chemical analysis}

For the purpose of chemical analysis the mantle flesh and flesh from the arms together with edible flesh from head were sampled separately and after passing it through a mincing machine with a strainer eyelet diameter of $15 \mathrm{~mm}$, were homogenized in order to obtain a uniform mass. The stuffing was collected and placed on Petrie plates and immediately sampled for chemical analysis.

\section{Chemical methods}

Water was determined by drying method at a temperature of $105^{\circ} \mathrm{C}$. Nitrogen and non-protein nitrogen (after its extraction in a 10 per cent solution of trichloroacetic acid) were determined by Kjeldhal's method, using for the ammonia destillation "macro"-type Parnas-Wagner apparatus.

Protein nitrogen was determined from the difference between nitrogen and non-protein nitrogen.

Protein fractions were determined by Łazarewski's method (1955). Flesh samples weighing 5 and 2.5 grammes respectively were extracted three times, simultaneously with water and 0.05 per cent sodium hydroxide solution. The 
content of protein nitrogen in particular extracts was determined by Kje] dahl's method after inclusion of proteins by trichloroacetic acid which had a 7.5 per cent final solution. The difference between the protein dissolving in 0.05 per cent sodium hydroxide solution and that dissolving in water, was described as miophybrylic protein, which in this case was composed of the globulin and residual intracellular protein.

The caloric value of the cuttlefish flesh was obtained after summing up the caloric values calculated for the individual food components present in 100 grammes of the sample examined. In calculating the caloric value of the proteins, fats and carbohydrates, Atwater's coefficients were applied (ref. Wi e r z c how s ki et. al.,1958), i.e. for $1 \mathrm{~g}$ of fat - $9 \mathrm{kcal}$, for $1 \mathrm{~g}$ of proteins - $4 \mathrm{kcal}$, for $1 \mathrm{~g}$ of carbohydrates - $4 \mathrm{kcal}$. Carbohydrates were calculated from the difference obtained after substraction from 100 the sum of individual percentage contents of proteins, fats, water and ash.

\section{Quality and quantity analysis of amino acids}

Free amino acids were extracted from the cuttlefish tis sue by Jones 'method (1955), purified and concentrated by Awapara's method (1948), applying own modification (K o ła k o w s k i, D a b r o w s k i, 1967). Amino acids bound in the protein were determined from the tissue precipitate obtained after extraction of free amino acids. The precipitate taken from the filter was dried at a temperature of $37^{\circ} \mathrm{C}$ under decreased pressure and then ground into powdered meal. Hydrolisis of proteins was carried out simultaneously in $6 \mathrm{n}$ Hydrochloric acid at a temperature of $105^{\circ} \mathrm{C}$ for 24 hours and in a. saturated solution of barium hydroxide at a temperature of $125^{\circ} \mathrm{C}$ for 20 hours (B 1 ock, D u r u m and $Z$ we i g, 1955). Separation of free amino acids from the boun amino acids was carried out by combined chromatography and low-voltage electrophoresis method ( $\mathrm{P}$ o d e s z e w s k i, 1962), applying the following conditions: in the first direction ascending chromatography in second order $n$-butylalcohol system: formic acid: water $(75: 15: 10$ respectively) for 32 hours $(2 \times 16$ hours ) and in the other direction, perpendicular to the first one, electrophoresis in a system phabt $1.9 /$ water: acetic acid: formic acid in ratio: $15: 3: 1$ at a voltage of $350 \mathrm{~V}$ and amperage of from 1.0-1.6 ma/cm sheet width of Whatman No.3 paper for 2.25 hours.

After electrophoresis, chromatograms were dried at room temperature until the smell disappeared and were then sprayed with 0.25 per cent acetone solution of ninhydrine with water and acetic acid added (B o d e, 1955) and developed in a dark room at a temperature of $18^{\circ} \mathrm{C}$ for 24 hours .

Quantity determination of amino acids was carried out by $\mathrm{F}$ i s c h e r- D o e rfe 1 method (1953), applying calibration curves plotted on the amino acids English standards ("Shandon" - Standard Solution for Paper Chromatography).

\section{RESULTS}

Morphometric analysis carried out on 32 pieces of cuttlefish showed that with an average length per piece, amounting to $24.5 \mathrm{~cm}$ (from 20.1 to $29.5 \mathrm{~cm}$ ), 
total yield of edible flesh was 65.7 per cent. The edible weight ratio of mantle is approximately $2.2: 1$. The yield of edible flesh increases with length and weight of the cuttlefish.

Basic chemical composition

Table 1 gives water, fat, ash, total nitrogen and non-protein nitrogen content in cuttlefish flesh. The first two columns contain the results obtained from the chemical analysis carried out on the edible flesh of the mantle and the flesh from arms and head separately. The last colum of this table gives the average chemical composition of edible meat of the whole cuttlefish, calculated from data from the above-mentioned two columns, and on the basis of the percentage participation of the mantle and arms together with head in the total flesh yield. Since the ratio of the edible mantle flesh and the edible flesh from arms and head is 2.2:1 respectively, by multiplying each result received for the mantle by 2.2 , then adding to this the result that received for arms and head flesh and dividing this sum by 3.2 , an average final result equal to the edible flesh of the whole cuttlefish was obtained.

$\mathrm{T}$ a b 1 e 1

Water, fat, ash, total nitrogen and protein nitrogen content in edible cuttlefish Sepia sp.) flesh

\begin{tabular}{|c|c|c|c|c|c|c|}
\hline \multirow[t]{2}{*}{ Kind of flesh } & \multirow{2}{*}{$\begin{array}{l}\text { Water } \\
(\%)\end{array}$} & \multirow{2}{*}{$\begin{array}{l}\text { Fat } \\
(\%)\end{array}$} & \multirow{2}{*}{$\begin{array}{l}\text { Ash } \\
(\%)\end{array}$} & \multicolumn{2}{|c|}{$\begin{array}{c}\text { Total nitrogen } \\
(\%)\end{array}$} & \multirow{2}{*}{$\begin{array}{l}\text { Non-pro- } \\
\text { tein ni- } \\
\text { trogen }(\%\end{array}$} \\
\hline & & & & $\mathrm{N}$ & $\mathrm{Nx} 6,25$ & \\
\hline Mantle & 76.66 & 0.23 & 1.62 & 3.009 & 18.81 & 0.814 \\
\hline $\begin{array}{l}\text { Arms together } \\
\text { with part of } \\
\text { head }\end{array}$ & 78.77 & 0.29 & 1.48 & 2.747 & 17.17 & 0.598 \\
\hline
\end{tabular}

As can be seed from data inserted in Table 1 , the edible flesh of the whole cuttlefish contains 77.3 per cent water, 0.25 per cent fat, 1.58 per cent ash and 18.29 per cent total protein, 74.58 of which comprises specific protein. Non-protein nitrogen amounts to 0.746 per cent on average.

The mantle flesh is richer in dry mass than the arms and head flesh (by approx. 9.94 per cent), in ash (by 9.46 per cent), in total protein (by 9.54 per cent) and in non-protein nitrogen (by 36.12 per cept), but the content of fat and specific protein is almost the same in both kinds of flesh.

\section{Characteristics of proteins}

In order to give general characteristics of the cuttlefish flesh proteins, analysis was carried out with respect of solubility in the relevant solutions in such a manner as to enable determination of the basic protein fractions. Results are given in Table 2 . 
Characteristics of edible cuttlefish (Sepia sp.) flesh proteins

\begin{tabular}{|c|c|c|c|c|c|c|c|c|c|c|}
\hline \multirow{3}{*}{ Kind of flesh } & \multicolumn{10}{|c|}{$\mathrm{g} / 100 \mathrm{~g}$ fresh flesh } \\
\hline & \multicolumn{2}{|c|}{ Pure protein } & \multicolumn{2}{|c|}{$\begin{array}{l}\mathrm{H}_{2} \mathrm{O} \text {-soluble } \\
\text { protein }\end{array}$} & \multicolumn{2}{|c|}{$\begin{array}{l}0.05 \% \mathrm{NaOH}-\text { so- } \\
\text { luble prot:ein }\end{array}$} & \multicolumn{2}{|c|}{ Residue: $d-c$} & \multicolumn{2}{|c|}{$\begin{array}{l}\text { Stroma protein } \\
\text { (residue: } \mathrm{b}-\mathrm{d} \text { ) }\end{array}$} \\
\hline & $\mathrm{N}$ & $\mathrm{Nx} 6.25$ & $\mathrm{~N}$ & $\mathrm{~N} \times 6.25$ & $\mathrm{~N}$ & $\mathrm{Nx} 6.25$ & $\mathrm{~N}$ & $\mathrm{Nx} 6.25$ & $\mathrm{~N}$ & $\mathrm{Nx} 6.25$ \\
\hline $\mathrm{a}$ & \multicolumn{2}{|c|}{$\mathrm{b}$} & \multicolumn{2}{|c|}{ c } & \multicolumn{2}{|c|}{$\mathrm{d}$} & \multicolumn{2}{|c|}{ e } & \multicolumn{2}{|c|}{$\mathrm{f}$} \\
\hline Mantle & 2.225 & 13.91 & 0.384 & 2.40 & 1.714 & 10.71 & 1.330 & 8.31 & 0.511 & 3.19 \\
\hline $\begin{array}{l}\text { Arms together } \\
\text { with part of } \\
\text { head }\end{array}$ & 2.149 & 13.43 & 0.529 & 3.31 & 1.608 & 10.05 & 1.079 & 6.74 & 0.541 & 3.38 \\
\hline $\begin{array}{l}\text { Edible flesh of } \\
\text { whole cuttle- } \\
\text { fish }\end{array}$ & 2.201 & 13.76 & 0.429 & 2.68 & 1.681 & 10.51 & 1.251 & 7.82 & 0.520 & 3.25 \\
\hline
\end{tabular}

x) results recived from calculations. 
It was stated 76.3 per cent of all the proteins of cuttlefish flesh is composed of soluble proteins, the remaining 26.63 per cent (in relation to the specific protein) connective tissue proteins, so called "stroma" proteins, are non-soluble in 0.05 per cent sodium hydroxide solution. Protein dissolving in water, socalled "sarcoplasmic" piroteins amount to 19.49 per cent of the total amount of proteins, and miophybrylic proteins (difference: d-c) 56.83 per cent (Table 2).

In spite of the significant similarity of both kinds of flesh as regards the total specific protein content, they differ considerably as to the content of the individual protein fractions. The mantle flesh is richer in miophybrylic protein by 23.26 per cent that the flesh from the arms and head, but has approximately 37.8 per cent less sarcoplasmic protein. In relation to specific protein stroma protein amounts to 22.96 per cent of the mantle flesh and 25.17 per cent of the flesh from the arms and head.

\section{Free amino acids}

It was stated that there are 20 free amino acids in the alcoholic extract of the cuttlefish flesh which, excluding the glutamine and aminobutyric acid, were also quantitatively determined. Results are given in Table 3 and Fig. 2 .

$\mathrm{T}$ a b l e 3

Free amino acid composition of edible cuttlefish (Sepia sp.) flesh

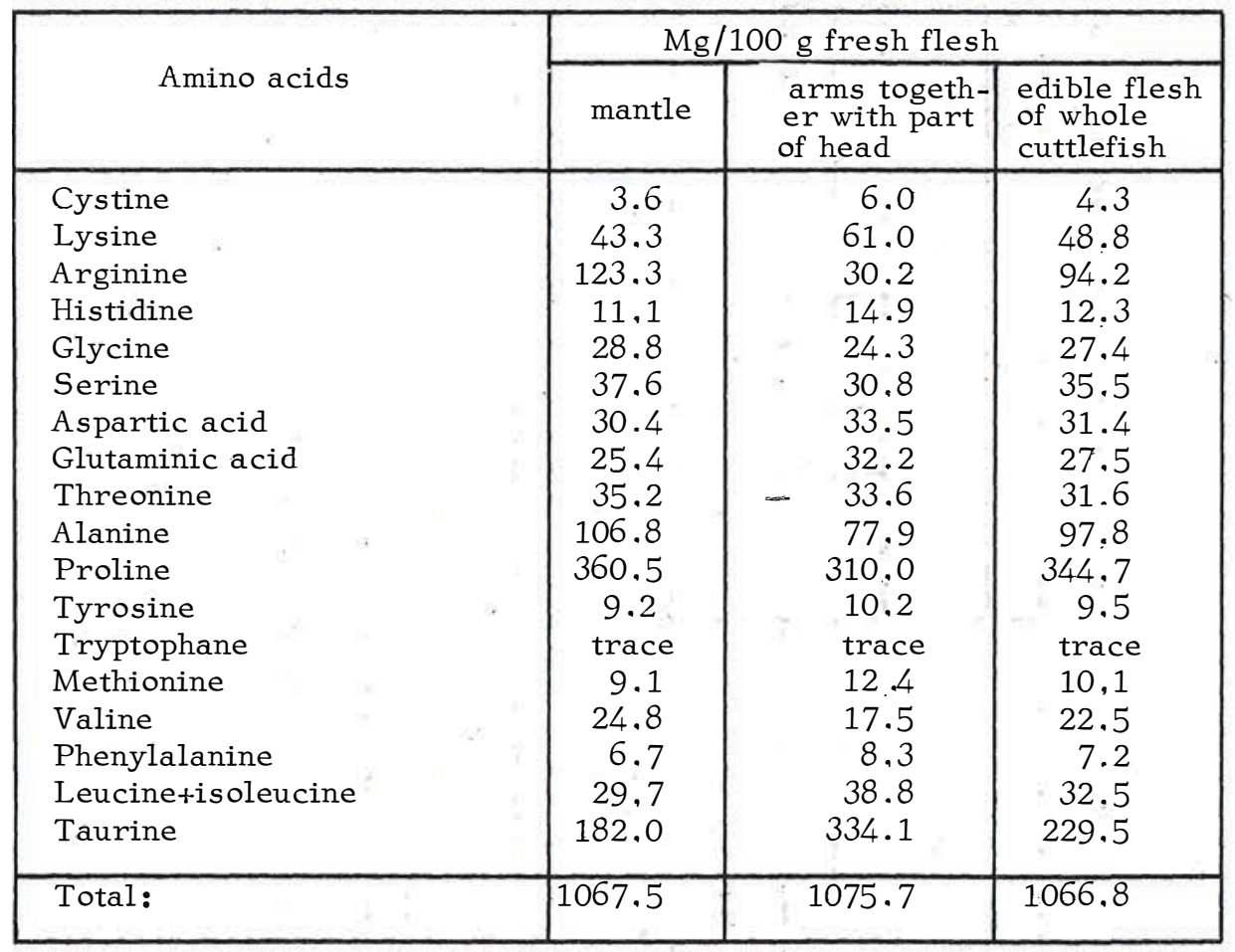



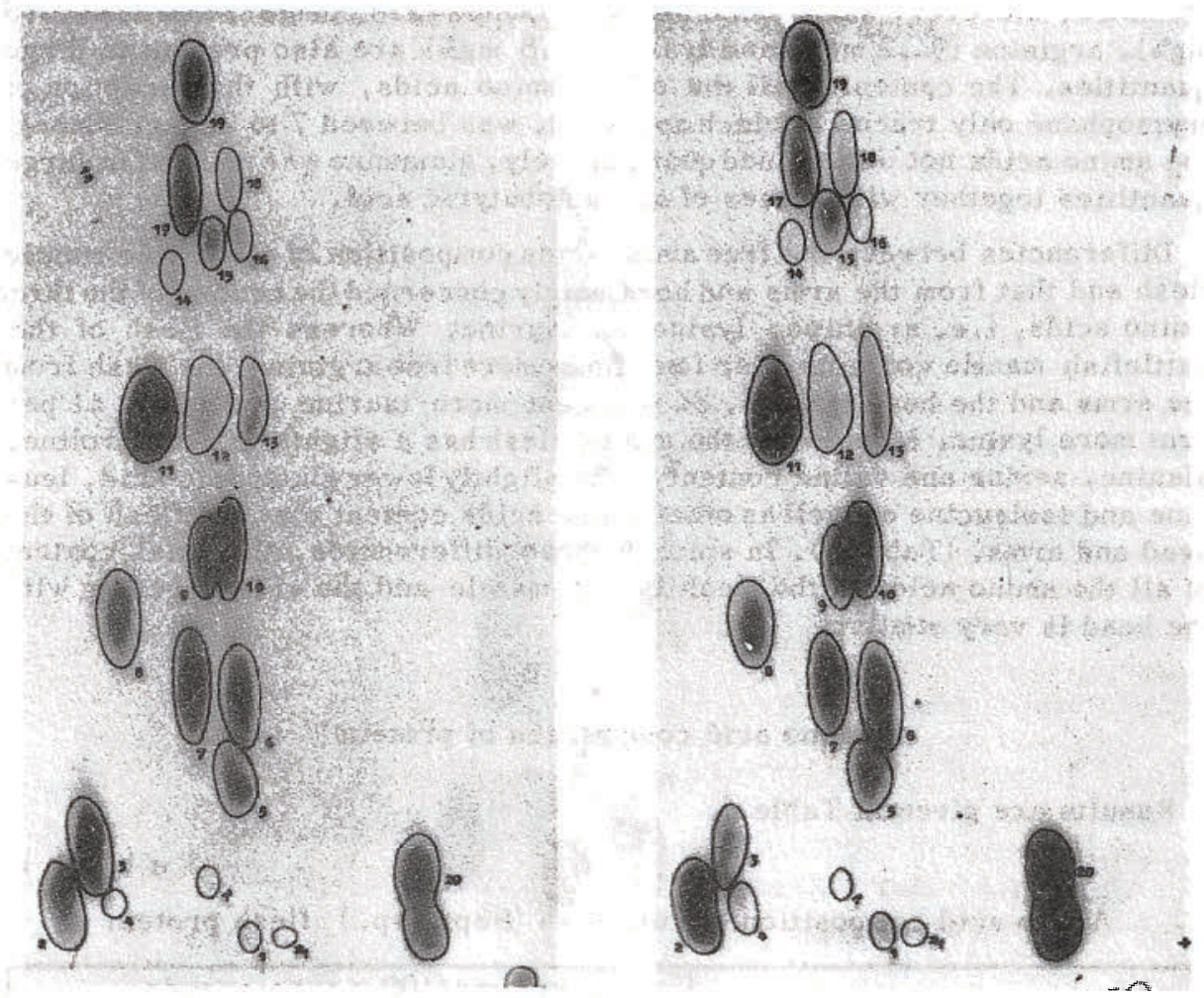

Fig.1. Chromatoelectropherograms of free amino acids of cuttlefish

(Sepia spp.) flesh.

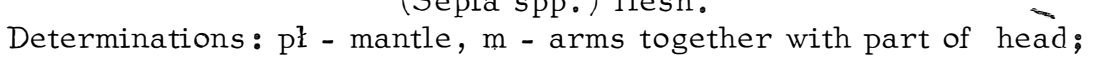
1.1 - cystine+cysteine, 2 - lysine, 3 - arginine, 4- histidine, 5 glutamine, 6 - aspartic acid, 7 - serine, 8 - glycine, 9 - threonine, 10 - glutaminic acid, 11 - alanine, 12 - proline, 13 - tyrosine, 14 aminobuturic acid, 15 - methionine, 16 - tryptophane, 17 - valine, 18 - phenylalanine, 19 - leucine+isoleucine, 20 - taurine, $x_{1}, x_{2}$ unidentified compounds

Each result given in the twafirst columns of Table 3 is the mean arithmetic value calculated from nine parallel determinations. Results in the last coiumn (for the edible flesh of the whole cuttlefish) were calculated as in the previous tables-from data of the two first columns, based on the assumption that weight ratio of the edible mantle flesh to that of the head and arms is 2.2.:1. Results in the last column of Table 3 are theoretically equal to such contents of free amino acids in the flesh as could be obtained when analysing the edible flesh of the whole cuttlefish as a single sample, not distinguishing it into mantle and arms together with head.

As can be seen from data inserted in Table 3, proline is present among the free amino acids in large quantities; its content amounting to an average 
$344.7 \mathrm{mg} \%$, i.e. over 32 per cent of all the amino acids quantitatively determined. Morever, such amino acids as taunine $(229.5 \mathrm{mg} \%)$, alanine $(97.8$ $\mathrm{mg} \%)$, arginine $(94.2 \mathrm{mg} \%$ ) and lysine (48.8 mg\%) are also present in large quantities. The content of all the other amino acids, with the exception of tryptophane only traces of which appeared, was between 7 to $36 \mathrm{mg}$. Among the amino acids not determined quantitatively, glutamine was present in large quantities together with traces of $\alpha$-aminobutyric acid.

Differencies between the free amino acids composition of the edible mantle flesh and that from the arms and head mainly concerned the content of the three amino acids, i.e. arginine, lysine and taurine. Whereas the flesh of the cuttlefish mantle contains over four times more free arginine, the flesh from the arms and the head has abt. 84 per cent more taurine and about 41 per cent more lysine. Moreover, the mantle flesh has a slightly higher proline, alanine, serine and valine content, but a slightly lower glutaminic acid, leucine and isoleucine as well as other amino acids content then the flesh of the head and arms. (Table 3). In spite of these differencies, the total content of all the amino acids in the flesh of the mantle and the arms together with the head is very similar.

Amino acid composition of protein

Results are given in Table 4 .

T a b l e 4

Amino acid composition of cuttlefish (Sepia sp.) flesh protein

\begin{tabular}{|l|r|r|r|}
\hline \multirow{2}{*}{ Amino acids } & \multicolumn{3}{|c|}{$\mathrm{g}$ amino acid/100 g pure protein } \\
\cline { 2 - 4 } & mantle & $\begin{array}{c}\text { arms togeth- } \\
\text { er with part } \\
\text { of head }\end{array}$ & $\begin{array}{c}\text { edible flesh } \\
\text { of whole } \\
\text { cuttlefish }\end{array}$ \\
\hline Cystine & 2.57 & 2.55 & 2.56 \\
Lysine & 10,16 & 9.06 & 9.81 \\
Arginine & 9.12 & 9.46 & 9.22 \\
Histidine & 2.29 & 2.22 & 2.27 \\
Glycine & 3.96 & 4.32 & 4.07 \\
Serine & 4.63 & 4.41 & 4.56 \\
Aspartic acid & 11.21 & 10.76 & 11.06 \\
Glutaminic acid & 13.07 & 12.71 & 12.96 \\
Threonine & 5.16 & 5.01 & 5.11 \\
Alanine & 5.55 & 5.41 & 5.51 \\
Proline & 4.45 & 4.68 & 4.52 \\
Tyrosine & 2.56 & 2.84 & 2.65 \\
Tryptophane & 1.23 & 1.21 & 1.22 \\
Methionine & 3.02 & 3.31 & 3.11 \\
Valine & 4.37 & 4.54 & 4.42 \\
Phenylalanine & 3.88 & 4.07 & 3.94 \\
Leucine+isoleucine & 12.63 & 13.21 & 12.81 \\
\hline
\end{tabular}


It was stated that 18 basic amino acids (Fig.3) are present in the protein of cuttlefish meat, in which are all the egzogenic amino acids.

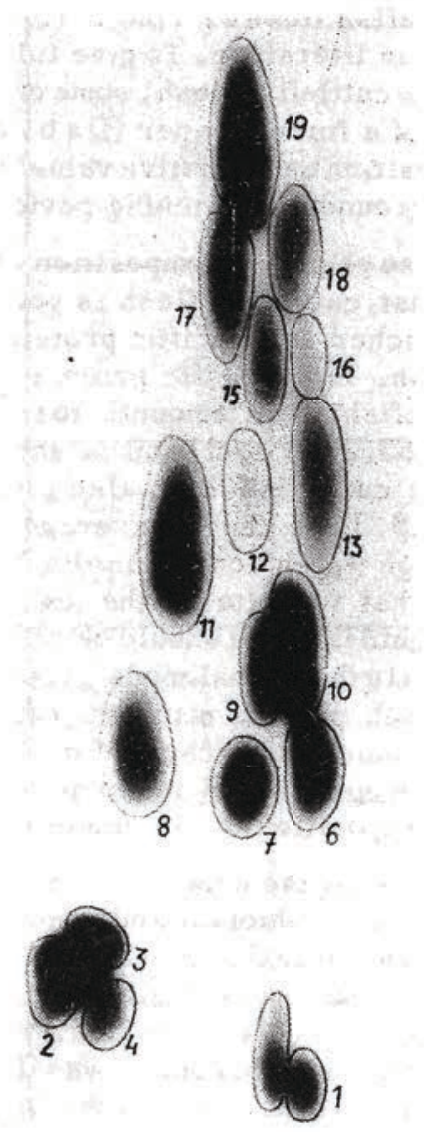

Fig.2. Chromatoelectropherograms of acid protein hydrolysatets of cuttlefish (Sepia sp.) flesh. Determinations (see Fig.1)

In comparison with fish ( $\mathrm{B} \mathrm{r}$ a e k k a $\mathrm{n}$ and $\mathrm{B} \circ \mathrm{g} \mathrm{e}, 1962$ ) the protein of cuttlefish is richer in cystine, lysine, arginine, proline and methionine and poorer in glycine, alanine, tyrosine, serine, glutaminic acid and valine. The amounts of other amino acids in cuttlefish are nearly the same as in fish.

The protein of the edible mantle flesh has a slightly higher content of lysine, serine, asparatic acid and glutaminic acid than that of the arms and head flesh, but it has a lower glycine, phenyloalanine, methionine, proline, tyrosine and leucine and isoleucine content. 


\section{DISCUSION}

In this paper, investigations were carried out on the chemical composition and nutritive value of cuttlefish flesh with the aim of supplementing the shortage of data on this subject in literature. To give fuller characteristics of the chemical composition of the cuttlefishflesh, some of the results were compared with the respective results of a former paper ( $\mathrm{d}$ a b row ski et al., 1969), describing chemical composition and nutritive value of squid flesh, originating from the same fishing ground and catching period.

From the comparison of the chemical composition of these two cephalopods (Table 5) it can be seen that, cuttlefish flesh is poorer than that of squid in fat and total protein, but richer in specific protein, in spite of the higher content of water in the flesh. The specific protein content, when converted into dry mass, in the cuttlefish flesh amounts to: mantle - 59.6 per cent; arms together with head - 63.2 per cent; and in squid flesh - 54.7 and 57.1 per cent respectively. The cuttlefish flesh also gives way to squid flesh as regards the caloricity, by 8.3 per cent on average, which is mainly caused by the low fat and fairly high water content in the fless of this cephalopods. It is presumed, however, that in spite of the lower caloricity in cuttlefish flesh, as compared with squidflesh, it should be characterized by relatively high biological assimilation in the cephalopods group. It is indicated, among others, by the relatively high protein nitrogen ratio to the total nitrogen, which in cuttlefish flesh amounts on average to 76.68 per cent (in squid flesh - 70.73 per cent) a large proportion of amino acids in the nonprotein acids and favourable chemical composition of the protein.

Cuttlefish protein contains all the egzogenic amino acids, and as regards lysine, arginine, tryptophane, methionine and threonine content, is superior to that of the majority of fish (Braekkan and Boge) and other animal products (Block and Boiling 1951). In our investigations it was also stated that the amount of such egzogenic amino acids as lysine, hystidine and valine and others such as cystine, serine and threonine was higher in the protein of cuttlefish than in the protein of squid flesh. But the protein of squid flesh was superior to that of the cuttlefish as regards the amounts of methionine, phenyloalanine, tryptophane, glycine and glutaminic acid. Moreover, a characteristic feature of the proteins of both cephalopodos is the relatively low tyrosine and hystidine content.

The proteins of cuttlefish flesh also differ from those of squid flesh as regards the composition of particular fractions. Sarcoplasmic proteins comprise 19.94 per cent of cuttlefish flesh. 
$\mathrm{Ta} b \mathrm{e} 5$

Comparison between cuttlefish (Sepia sp.) and squid (Loligo sp.) flesh chemical composition and caloric value

\begin{tabular}{|c|c|c|c|c|c|c|c|c|}
\hline Kind of flesh & Species & $\begin{array}{l}\text { Water } \\
(\%)\end{array}$ & $\begin{array}{l}\text { Fat } \\
(\%)\end{array}$ & $\begin{array}{l}\text { Ash } \\
(\%)\end{array}$ & $\begin{array}{c}\text { Total } \\
\text { protein } \\
(\%)\end{array}$ & $\begin{array}{c}\text { Pure } \\
\text { protein } \\
(\%)\end{array}$ & $\begin{array}{l}\text { Pure protein } \\
\text { as percentage } \\
\text { of total pro- } \\
\text { tein }\end{array}$ & $\begin{array}{l}\text { Calo- } \\
\text { ricity } \\
\text { Kcal/ } \\
100 \mathrm{~g}\end{array}$ \\
\hline Mantle & $\begin{array}{l}\text { cuttlefish } \\
\text { squid }\end{array}$ & $\begin{array}{l}76.66 \\
75.77\end{array}$ & $\begin{array}{l}0.23 \\
0.72\end{array}$ & $\begin{array}{l}1.62 \\
1.42\end{array}$ & $\begin{array}{l}18.81 \\
19.29\end{array}$ & $\begin{array}{l}13.91 \\
13.26\end{array}$ & $\begin{array}{l}73.95 \\
68.74\end{array}$ & $\begin{array}{l}88.03 \\
94.84\end{array}$ \\
\hline $\begin{array}{l}\text { Arms together } \\
\text { with part of } \\
\text { head }\end{array}$ & $\begin{array}{l}\text { cuttlefish } \\
\text { squid }\end{array}$ & $\begin{array}{l}78.77 \\
77.69\end{array}$ & $\begin{array}{l}0.29 \\
0.87\end{array}$ & $\begin{array}{l}1.48 \\
1.51\end{array}$ & $\begin{array}{l}17.17 \\
17.53\end{array}$ & $\begin{array}{l}13.43 \\
12.75\end{array}$ & $\begin{array}{l}78.21 \\
72.73\end{array}$ & $\begin{array}{l}80.45 \\
87.55\end{array}$ \\
\hline
\end{tabular}




\section{REFERENCES}

A w a p a r a J., 1948: Application of paper chromatography to the estimation of free amino acids in tissues. Arch. Biochem., 19, 172-173.

B 1 ock R.J., and B o i ling D., 1951: The amino acid composition of proteins and foods, Charles C. Thomas, Springfield.

B lock R.J., Durrum E.L. and Z we ig G., 1955: A manual of paper chromatography and paper electrophoresis, Academic Press, Inc., Publisheries, New York. :64-83.

B o d e F., 1955: Eine Vereinfachung und Verbesserung der Methode zur quantitativen Bestimmung von Aminosäuren und Peptiden mittels des Ninhydrin-Kupferkomplexes. Biochem. Zeit. 326: 433-435.

B ra e k k a n O.R., and B o g r G., 1962: Reports Technol. Research Norwegian Fish. Industry IV, 3 .

D ąbrowski T., Kołakowski E., Kołakowska A., and K a r n i cka B., 1969: Studies on chemical composition of squid (Loligo sp.) meat as related to its nutritive value (unpublished data).

F is he $r$ F.G. und Dörfe 1 H., 1953: Zurquantitativen Auswertung der Papierchromatogramme von Eiweiss-Hydrolysaten. Biochem. Zeit. $324: 544-566$.

Food and Agriculture Organisation U.N. Yerbook Fishery Statistics, 1967.

I t o K., 1957: Amino acid composition of the muscle extracts of aquatic animals. Bull. Japan. Soc. Sci. Fisheries. 23: 497-500.

J e b s e n J.W., 1962: Proteins infishmuscle, in "Fish in Nutrition" p.68 (H.Heen and R. Krauzer eds.), Fishing News, Inc., London.

J o n e s N.R., 1955: The free amino-acids of fish. I. - Taurine in the skeletal muscle of codling (Gadus callarias). J.Sci.Fd.Agric. 6:3-8.

K 1 a r k M.R. 1964: Ekonomičeskoje značenijekalmarov Severnoj Atlantiki (Economical signification of North Atlantic squids) Rybnoe Khoz. 9: 86-89.

K ○ ł a k ow ski E., and D ą b r o w s ki T., 1967: Untersuchungen über die Veränderungen der Stickstoffsubstanz im Gewebe des Ostseeherings (Clupea harengus membras L.) bei verschiedenen Lagerungsbedingungen. 1. Mitt. Die qualitativen Veränderungen der freien Aminosäuren. Die Nahrung. 11: 493-500.

L a g u nov L.L., and R e hin a N.I., 1967: Tehnologija produktov iz morskih becpozvonočnyh (Technology of products with sea invertebrates). Moskva, Piščevaja Promyšlennost. (Russian).

L a z a r e v s kij A.A., 1955: Thehno-himičeskij kontrol v ryboobrabatyvajuščej promyšlennosti (Chemical technological control in fish industry). Moskva, Piščepromizdat(Russian). 
M a ci e j c z y k J., 1968: Badania technolcgiczne głowonogów. (Technological investigation of squids). Biuletyn Informacyjny ZGR. (Poland), No.1, 113-120.

P o d e s z e w s k i Z., 1962: Chromatoelektroforeza aminokwasów. (Electrophoretic separation of amino-acids). Rocz-i Państw.Zakł.Hig., 13, 71-75 (Engl.summ.),

T a k a h a s hi T., 1965: Squid meat and its processin "Fish as Food", (Georg Borgstrom ed.), Academic Press Inc., New York and London, Vol. IV, pp. 339-354.

\section{BADANIA NAD SKEADEM CHEMICZNYM I WARTOŚCIĄ ODŻYWCZĄ MIĘSA SEPII (SEPIA SP.) \\ Streszczenie}

Zbadano wydajność i skład chemiczny jadalnego mięsa sepii z podziałem na płaszcz i ramiona z głową.

Mięso jadalne sepii zawiera średnio 77,31\% wody, 0,25\% tłuszczu, $1.58 \%$ popiołu i 18,29\% białka ogólnego, które w 74,5\% składa się z białka właściwego. Zawartość azotu niebiałkowego wynosi średnio 0,746\%. Mięso płaszcza jest bogatsze od mięsa ramion i głowy w suchą masę (o ok.9,94\%), popiół (o 9,46\%), białko ogólne $(09,54 \%)$ i azot niebiałkowy (o36,12\%). Zawartość tłuszczu i białka właściwego jest w obu rodzajach mięsa bardzo zbliżona.

Poza tym zbadano skład frakcji białkowych, skład aminokwasowy białek, skład aminokwasów wolnych i kaloryczność mięsa sepii. Stwierdzono, że białko mięsa sepii jest szczególnie bogate pod względem zawartości lizyny, argininy, tryptofanu, metioniny, treoniny i cystyny. W stanie wolnym w mięsie sepii najliczniej występują takie aminokwasy jak prolina, tauryna, alanina, arginina i lizyna.

W pracy przeprowadzono także porównanie składu chemicznego mięsa sepii ze składem chemicznym mięsa kałamarnicy pochodzącej z tego samego łowiska i okresu połowowego.

ИССЛЕДОВАНИЯ ХИМИЧЕСКОГО СОСТАВА И ПИТАТЕЛЬНОЙ ЦЕННОСТИ МЯСА СЕПИИ (Sepia sp.)

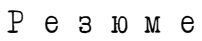

Исследован химичесний состав съедобных частей мяса сепии, отдельно для мантии и шупалег с головой. 
Съедобаная часть сепии содержпт в среднием $77,31 \%$ воды, 0,25\% жира, $1,58 \%$ золы и 18,29\% общего белка, которое на $74,5 \%$ состоит из собственного белка. Содержание небелгового азота составляет в среднием 0,746\%. Мясо мантии содержит больше сухой массы (на около 9,94\%), золы (на 9,46\%), общего белка (на 9,54\%) и небелкового азота (на $36,12 \%$ ), чем мясо шупалец с головой. Содержание жира и собственного белка, является в обеих видах мяса подобным.

Кроме того исследован состав белковых форакции, состав белковых аминокислот, состав свободных аминокислот и калорийность мяса сепии. Установлено, что белок мяса сепии содержит особенно много лизина, аргинина, триптофана, метионина, треонина и цистина. В свободном состоянии в мясе сепии в наиболышом количестве присутствуют қакие аминокислоты как пролин, таурин, аланин, аргинин ил лизин.

В работе проведено также сравнение химического состава мяса сепии с химическим составом мяса кальмаров присходящих из того же района лова и выловленных в тот же период, что взятые для анализа сении

\section{Address :}

Dr Edward Kołakowski

Katedra Technologii WSR

Szczecin, ul.Broniewskiego 1

Polska - Poland

Received 17.VI.1969 